\title{
Fate of the human $Y$ chromosome linked genes and loci in prostate cancer cell lines DU145 and LNCaP
}

\author{
Sandeep Kumar Yadav, Anju Kumari and Sher Ali
}

\begin{abstract}
Background: Prostate cancer is a known cause of mortality in men worldwide although the risk factor varies among different ethnic groups. Loss of the $Y$ chromosome is a common chromosomal abnormality observed in the human prostate cancer.

Results: We screened 51 standard sequence tagged sites (STSS) corresponding to a male-specific region of the $Y$ chromosome (MSY), sequenced the coding region of the SRY gene and assessed the status of the DYZ1 arrays in the human prostate cancer cell lines DU145 and LNCaP. The MSY was found to be intact and coding region of SRY showed no sequence variation in both the cell lines. However, DYZ1 arrays showed sequence and copy number variations. DU145 and LNCaP cells were found to carry 742 and 1945 copies of the DYZ1, respectively per 3.3 pg of genomic DNA. The DYZ1 copies detected in these cell lines are much below the average of that reported in normal human males. Similarly, the number of "TTCCA" repeat and its derivatives within the DYZ1 arrays showed variation compared to those of the normal males.

Conclusions: Clearly, the DYZ1 is maximally affected in both the cell lines. Work on additional cell lines and biopsied samples would augment our understanding about the susceptibility of this region. Based on the present work, we construe that copy number status of the DYZ1 may be exploited as a supplementary prognostic tool to monitor the occurrence of prostate cancer using biopsied samples.
\end{abstract}

Keywords: Prostate cancer, DU145, LNCaP, MSY, STS, DYZ1

\section{Background}

The incidence of prostate cancer $(\mathrm{PC})$ is increasing worldwide though varies amongst different ethnic groups [1]. It is a common malignancy affecting global population of men and is a significant cause of morbidity and mortality. The prevalence of this cancer is highest in the Western countries and lowest in the Asian countries [2]. Despite its high prevalence, very little is known about the molecular mechanism of its tumorigenesis.

Reports are there suggesting the involvement of chromosomes $1,5,6,7,8,10,12,13,17,18,20, \mathrm{X}$ and the $\mathrm{Y}$ encompassing several genetically susceptible loci [3] though their precise roles still remain unclear. The advanced stage of PC shows complex chromosomal changes

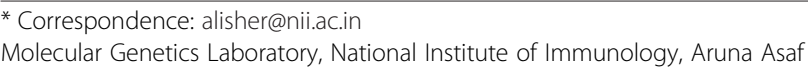

* Correspondence: alisher@nii.ac.in Ali Marg, New Delhi 110067, India
}

(c) 2013 Yadav et al.; licensee BioMed Central Ltd. This is an Open Access article distributed under the terms of the Creative Commons Attribution License (http://creativecommons.org/licenses/by/2.0), which permits unrestricted use, distribution, and reproduction in any medium, provided the original work is properly cited. accumulated during the tumour progression [3-7]. Loss of the $\mathrm{Y}$ chromosome is a common chromosomal abnormality observed in the human PC [8] and this occurs only in neoplastic, but not in stromal cells [9]. Loss of genetic material may lead to the loss of putative tumour suppressor genes, which will ultimately lead to cancer. This hypothesis is supported by the fact that a normal human Y chromosome transferred to a $\mathrm{Y}$ chromosome lacking PC cell line PC3, suppressed its tumorigenic property [8]. Genetic predisposition of certain Y chromosomal haplogroups towards PC strongly suggests a positive correlation $[1,10,11]$. However, study conducted on Korean population showed lack of association between Y chromosomal haplogroups and PC [12]. The involvement of several Y linked genes and loci have been reported to be associated with the progression of PC [13,14]. The male sex determining gene $S R Y$ is down regulated in $\mathrm{PC}$ and is a negative regulator of the androgen receptor [15]. SRY does not express in any adult 


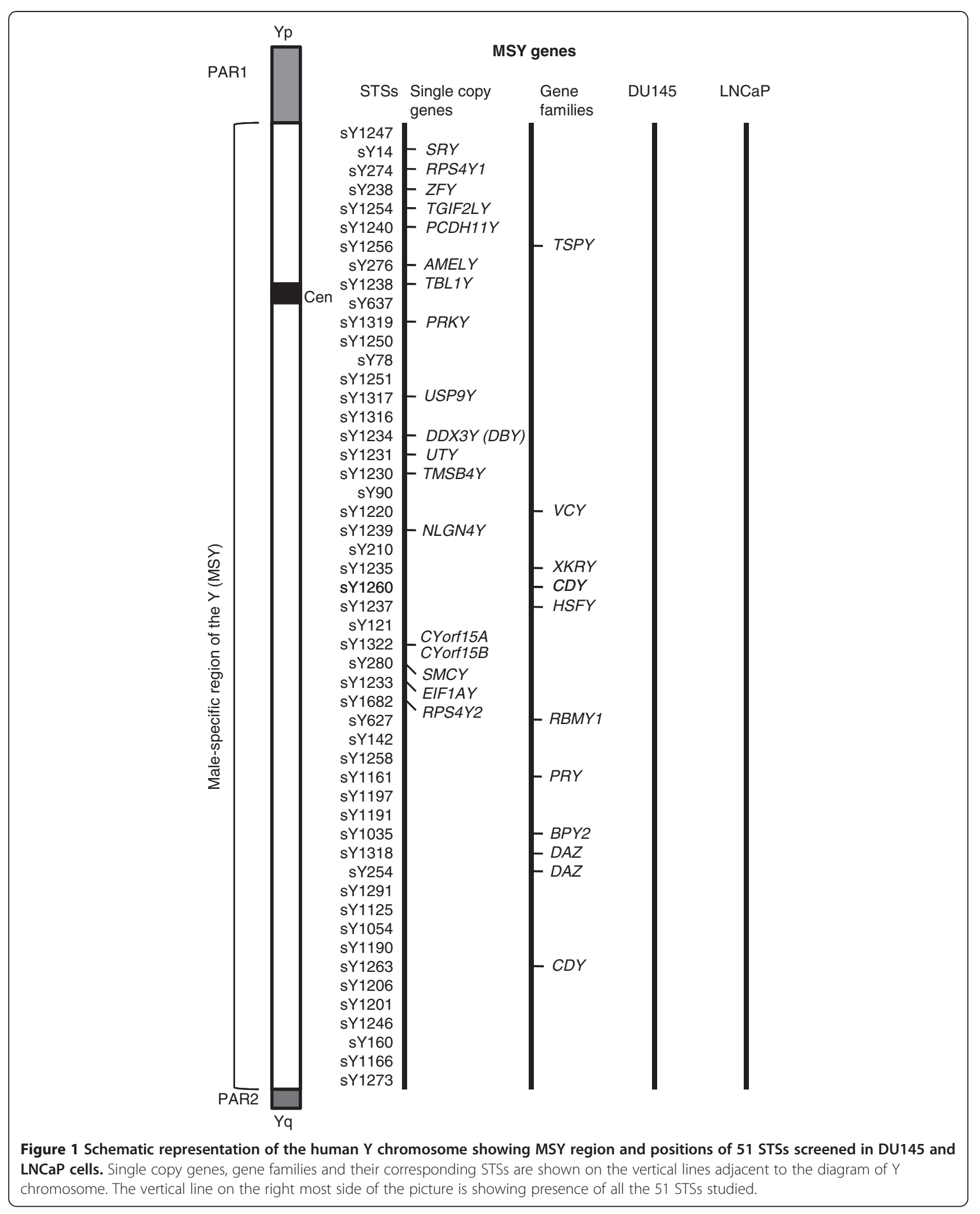


Table 1 List of STSs analyzed to ascertain the genetic integrity of the Y-chromosome in the prostate cancer cell lines DU145 and LNCaP

\begin{tabular}{|c|c|c|c|c|c|}
\hline Serial No. & STS Identifier & Location & Multi-Copy & $\begin{array}{l}\text { STS Status in } \\
\text { DU145 }\end{array}$ & $\begin{array}{c}\text { STS status in } \\
\text { LNCaP }\end{array}$ \\
\hline 1 & sY14 & SRY exon 1 & & + & + \\
\hline 2 & sY1240 & PCDH11Y intron 3 & & + & + \\
\hline 3 & sY276 & AMELY exon 4/intron 4 & & + & + \\
\hline 4 & sY1238 & TBLIY exon 11 & & + & + \\
\hline 5 & sY637 & PRKY 5' upstream of gene & & + & + \\
\hline 6 & sY1319 & PRKY 3' UTR & & + & + \\
\hline 7 & sY1250 & Proximal boundary of TSPY array & & + & + \\
\hline 8 & sY78 & Alpha satellite (DYZ3) sequences in centromeric region & * & + & + \\
\hline 9 & sY1251 & Boundary between centromere and $\mathrm{Yq}$ & & + & + \\
\hline 10 & sY1317 & USP9Y exon 3 & & + & + \\
\hline 11 & sY1316 & USP9Y exon 26 & & + & + \\
\hline 12 & sY1234 & DDX3Y (DBY) exon 9 & & + & + \\
\hline 13 & sY1231 & UTY exon 8 & & + & + \\
\hline 14 & sY1235 & XKRY exon 1 & * & + & + \\
\hline 15 & sY1260 & CDY2 exon 1 & * & + & + \\
\hline 16 & sY1237 & HSFY exon 2 & * & + & + \\
\hline 17 & sY121 & Immediately distal to palindrome P4 & & + & + \\
\hline 18 & sY1322 & Between CYorf15A \& CYorf15B & & + & + \\
\hline 19 & sY280 & JARIDID (SMCY) exon 9/intron 9 & & + & + \\
\hline 20 & sY1233 & EIF1AY exon 1 & & + & + \\
\hline 21 & sY1682 & RPS4Y2 exon 1 & & + & + \\
\hline 22 & sY627 & RBMY1 exon 12 & * & + & + \\
\hline 23 & sY1258 & Boundary between unique sequence u1 \& blue amplicon b1 in AZFC & & + & + \\
\hline 24 & sY1161 & $P R Y$ intron 2 & * & + & + \\
\hline 25 & sY1197 & Internal boundary of Palindrome P3 & & + & + \\
\hline 26 & sY1191 & Unique sequence $\mathrm{U} 3$ in $A Z F C$ & & + & + \\
\hline 27 & sY1035 & $B P Y 2$ intron 5 & * & + & + \\
\hline 28 & sY1318 & $D A Z$ exon 11 & * & + & + \\
\hline 29 & sY254 & $D A Z$ exon 3 & * & + & + \\
\hline 30 & sY1291 & Red/gray boundary in AZFC & & + & + \\
\hline 31 & sY1125 & Blue/gray boundary in AZFC & * & + & + \\
\hline 32 & sY1054 & Blue/yellow boundary in AZFC & * & + & + \\
\hline 33 & sY1190 & Yellow amplicon in AZFC & * & + & + \\
\hline 34 & sY1263 & CDY1 exon 1/intron 1 & * & + & + \\
\hline 35 & sY1206 & Yellow/green boundaries in AZFC & * & + & + \\
\hline 36 & sY1201 & Distal boundary of gray amplicon in AZFC & & + & + \\
\hline 37 & sY1256 & TSPY intron 5 & * & + & + \\
\hline 38 & sY1247 & Boundary between PAR1 and MSY & & + & + \\
\hline 39 & sY1230 & TMSB4Y exon 1/intron 1 & & + & + \\
\hline 40 & sY1166 & In MSY between distal Yq heterochromatin \& PAR2 & & + & + \\
\hline 41 & sY274 & RPS4Y1 intron 4 & & + & + \\
\hline 42 & sY1220 & VCY exon 2 & * & + & + \\
\hline 43 & sY90 & KALP intron 1 & & + & + \\
\hline
\end{tabular}


Table 1 List of STSs analyzed to ascertain the genetic integrity of the Y-chromosome in the prostate cancer cell lines DU145 and LNCaP (Continued)

\begin{tabular}{|c|c|c|c|c|c|}
\hline 44 & sY210 & STSP intron 5 & & + & + \\
\hline 45 & sY1254 & TGIF2LY exon 1 & & + & + \\
\hline 46 & sY1239 & NLGN4Y exon 1 & & + & + \\
\hline 47 & sY1273 & Near boundary between MSY \& PAR2 & & + & + \\
\hline 48 & sY238 & ZFY intron 2 & & + & + \\
\hline 49 & sY1246 & Proximal portion of distal Yq heterochromatin & & + & + \\
\hline 50 & sY142 & Proximal to $A Z F C$ & & + & + \\
\hline 51 & sY160 & Satellite-3 (DYZ1) sequences in distal Yq heterochromatin & * & + & + \\
\hline
\end{tabular}

Multi-copy STSs are indicated by star $\left(^{*}\right)$ and plus (+) sign denotes the presence of a particular STS.

male tissue except the adult testis. However, $S R Y$ is expressed in DU145 [16], androgen untreated LNCaP cells [13] and prostate adenocarcinoma cell lines. Thus, SRY gene seems to play an important role for the development and progression of $\mathrm{PC}$.

The human Y chromosome is male specific, constitutively haploid, passed on from father to son and largely escapes meiotic recombination. Approximately, 95\% (60 Mb) of the human Y chromosome represents non recombining region of $\mathrm{Y}$ (NRY), also known as MSY. Similarly, 5\% (3 $\mathrm{Mb})$ of the Y-chromosome is composed of pseudoautosomal region (PAR) necessary for the pairing with the sex chromosomes. There are 1287 MSY specific STS markers encompassing the human Y chromosome with an average spacing of $14 \mathrm{~Kb}$ spanning over 1698 loci [17]. Deletion mapping based on the STSs has advanced our understanding of the Y chromosome structure and functions. Previous studies were mostly conducted on three commercially available PC cell lines LNCaP, PC3 and DU145 using chromosome banding techniques [18], Fluorescence in situ hybridization (FISH) [19], Comparative genomic hybridization (CGH) [20], and Spectral karyotyping (SKY) [21,22]. However, none of these techniques provided evidence towards the involvement of Y chromosome linked genes and loci. In the present study, we studied DU145 (originated from the metastatic site brain of a 69 years old Caucasian male) and $\mathrm{LNCaP}$ (originated from the metastatic site left supraclavicular lymph node of a 50 years old Caucasian male) cell lines using 51 STSs specific to MSY. DU145 is Hypotriploid having both 61 and 62 chromosomes with highest rate of occurrence and carries single Y per cell. The Y chromosome of DU145 carries a translocated part of chromosome 20 [3]. $\mathrm{LNCaP}$ is hypotetraploid having 84 chromosomes occurring in $22 \%$ of the cells [23] and carries 2 Y chromosomes per cell [3].

Approximately, 20\% of the human Y chromosome harbours DYZ1 satellite sequence [24]. DYZ1 was identified as $3.4 \mathrm{~Kb}$ band generated on HaeIII digestion of the human male genomic DNA [25]. A normal human Y chromosome contains approximately 4000-4300 copies of the DYZ1 arrays [26]. Since DYZ1 copies do not participate in recombination, it was deduced to have no functional or evolutionary advantage [27]. However, this is now reported to play a crucial role in chromatin folding and maintenance of the structural integrity of the $Y$ chromosome [26].

With this background, we studied status of several Y linked genes and loci and assessed copy number variation of DYZ1 arrays using real time PCR in DU145 and LNCaP cell lines. In addition, we sequenced the 3564 bp unit of DYZ1 array and the coding region of $S R Y$ gene from these cell lines.

\section{Results}

\section{Status of the MSY region in DU145}

The genomic DNA from DU145 and LNCaP was screened for the presence or absence of 51 STSs specific to MSY (Figure 1 and Table 1). These STSs in both the cell lines were found to be intact.

\section{HERV15 provirus sequence recombination}

Human $A Z F a$ region contains HERV15 provirus A and $\mathrm{B}$ sequences and homologous recombination between these two regions accounts for most of the $A Z F a$ deletions [28]. The $A Z F a$ regions of DU145 and LNCaP Y chromosomes were found to remain intact showing the presence of $U S P 9 Y$ and $D B Y$ genes (Figure 2).

\section{Interstitial deletion mapping}

There are known deletion patterns observed in different clinical conditions e.g. $A Z F a$, P5- proximal P1, P5- distal $\mathrm{P} 1, A Z F_{C}, \mathrm{gr} / \mathrm{gr}, \mathrm{b} 1 / \mathrm{b} 2$ and $\mathrm{b} 2 / \mathrm{b} 3$ and TSPY-TSPY deletion [29-36]. We have screened STSs encompassing these regions which were found to remain intact in DU145 of LNCaP cells (Figure 3).

\section{DAZ SNV analysis}

The normal Y chromosome harbours four copies of $D A Z$ gene [37]. The SNV analysis of $D A Z$ was conducted using appropriate enzymes [38] to digest PCR products (Table 2). 


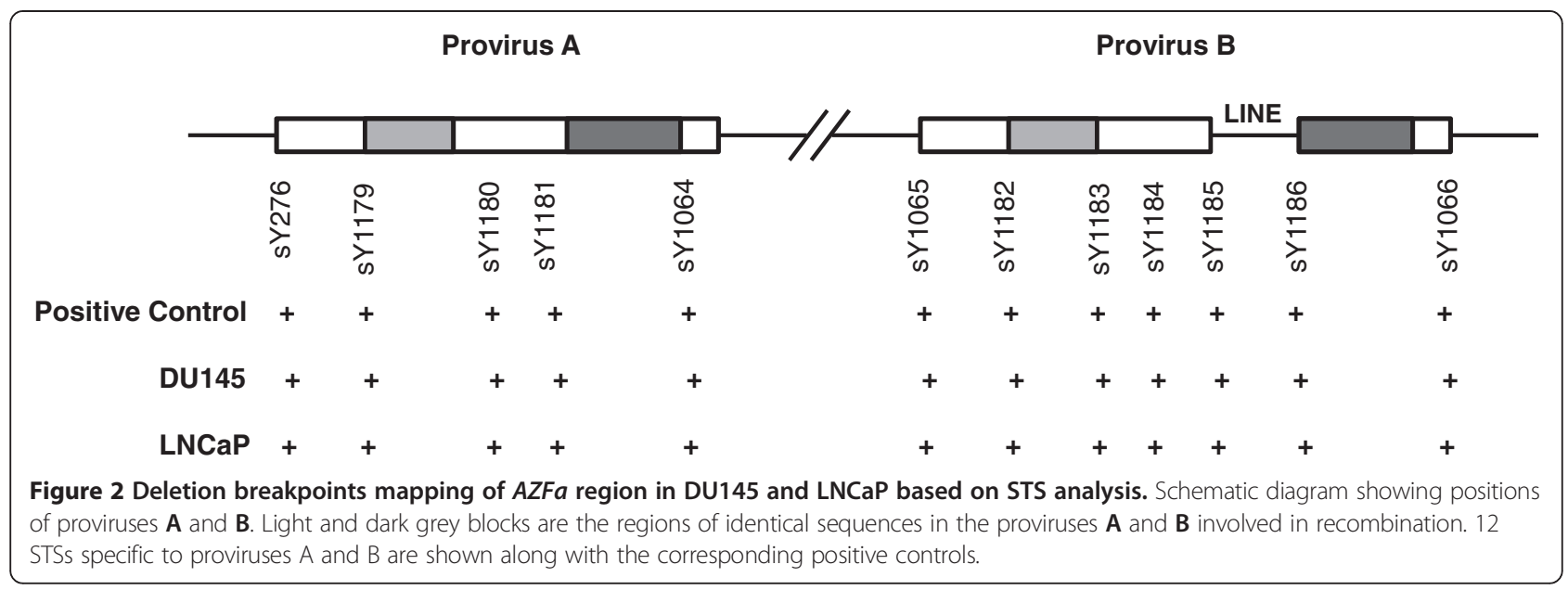

The $D A Z$ region in DU145 and $\mathrm{LNCaP}$ showed presence of both alleles $\mathrm{A}$ and $\mathrm{B}$ for the SNVs $(D A Z$ SNV_I, $D A Z-S N V \_I I, D A Z-S N V \_I I I, D A Z-S N V \_I V$,

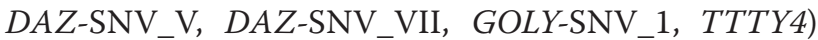
screened. For DAZ-SNV_VI and BPY2, DU145 showed both the alleles $\mathrm{A}$ and $\mathrm{B}$ while $\mathrm{LNCaP}$ had only allele A (Table 2).

\section{SRY gene sequence}

We amplified 824 bp fragment of the $S R Y$ exon having 615 bp long coding fragment (Table 3B), cloned and sequenced. The sequences of the SRY gene in both DU145 and LNCaP were found to be intact (see Additional file 1).

\section{Status of the DYZ1 array}

For ascertaining structural status of the DYZ1 array, 6 sets of primers were designed (Table 3A) to amplify 19 fragments (Table 4) from a single $3.56 \mathrm{~kb}$ array of DYZ1 (Figure 4). The analysis of all the 19 combinations showed intact DYZ1 arrays both in DU145 and LNCaP.
Copy number calculation of DYZ1 using real time PCR

We calculated DYZ1 copy number in DU145 and LNCaP by Real Time PCR using SYBR green chemistry employing absolute quantification method and a standard curve of cloned DYZ1 plasmid using ten-fold dilutions starting with 20 crore $\left(2 \times 10^{8}\right)$ copies. The amplification plot, dissociation curve and standard curve are given in Figure $5 \mathrm{~A}, \mathrm{~B}$, and $\mathrm{C}$, respectively. Figure 5D represents the number of DYZ1 copies. DU145 contains 742 copies, while LNCaP contains 1945 copies per 3.3 pg of genomic DNA.

\section{4 bp array sequence of DYZ1}

Four PCR amplified fragments (Figure 4, dark bar) were cloned and sequenced. Sequencing results showed insertion, deletion and several point mutations. Compared to normal sequences of the DYZ1, the number of highly abundant "TTCCA" repeats [25] and its derivatives per $3564 \mathrm{bp}$ (HaeIII fragment) were found to be different amongst normal, DU145 and LNCaP cells (Table 5 and

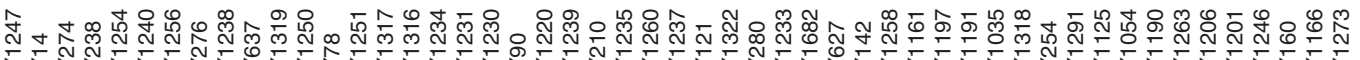

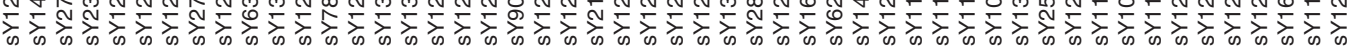

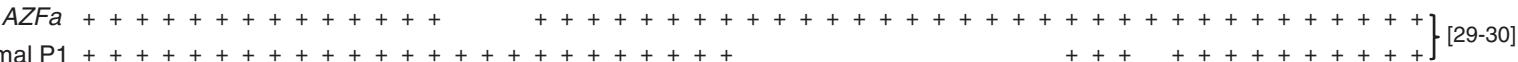

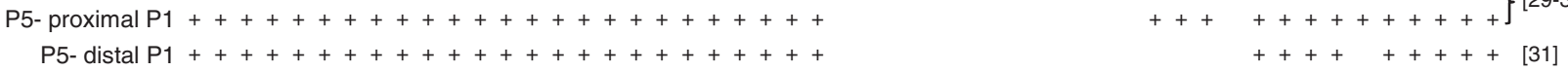

AZFC $+++++++++++++++++++++++++++++++++++\quad++++7$

gr/gr ++++++++++++++++++++++++++++++++++++++++++++++++++

b1/b3 $++++++++++++++++++++++++++++++++++\quad++++++++++++32-35]$

$\mathrm{b} 2 / \mathrm{b} 3++++++++++++++++++++++++++++++++++++++++++++++++++]$

TSPY-TSPY $++++++\quad++++++++++++++++++++++++++++++++++++++++[36]$

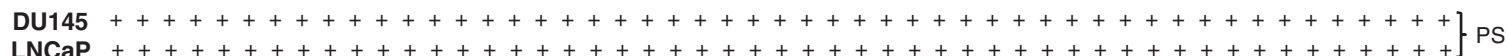

Figure 3 STS map showing common interstitial deletions of the human Y chromosome based on different studies conducted earlier. Plus sign and blank spaces denote the presence and absence of a particular STS, respectively. The corresponding references related to these studies are given on the right [see references 29-36]. Last row shows the results of the present study denoted as PS. 
Table 2 Details of the SNVs studied for DAZ, GOLY, BPY2 and TTTY4 genes

\begin{tabular}{|c|c|c|c|c|c|c|c|c|c|c|c|}
\hline Target & SNV & Oligos used & $\begin{array}{c}\text { Accession } \\
\text { no. }\end{array}$ & $\begin{array}{l}\text { Product } \\
\text { size }\end{array}$ & $\begin{array}{l}\text { Enzyme for } \\
\text { digestion }\end{array}$ & $\begin{array}{l}\text { Restriction } \\
\text { site }\end{array}$ & Fragments & Alleles & $\begin{array}{c}\text { Present in } \\
\text { copies }\end{array}$ & DU145 & LNCaP \\
\hline & \multirow[t]{2}{*}{ DAZ-SNV_I } & SA 770 CACAGGCACTCAGTAACTATCTC & \multirow[t]{2}{*}{ G73167 } & \multirow[t]{2}{*}{709} & \multirow[t]{2}{*}{ Fsp1 } & \multirow[t]{2}{*}{ TGC/GCA } & 709 & A & \multirow{2}{*}{$\begin{array}{c}1,2,3 \\
4\end{array}$} & \multirow[t]{2}{*}{$A \& B$} & \multirow[t]{2}{*}{$A \& B$} \\
\hline & & SA771CAGTGTTTCACCCACCACTTCTGGGT & & & & & $398+311$ & B & & & \\
\hline & \multirow[t]{2}{*}{ DAZ-SNV_II } & SA 446 GACATCCACGTCATTAACAAACG & \multirow[t]{2}{*}{ G73166 } & \multirow[t]{2}{*}{182} & \multirow[t]{2}{*}{ Mbol } & \multirow[t]{2}{*}{ /GATC } & 182 & A & \multirow{2}{*}{$\begin{array}{c}1 \\
2,3,4\end{array}$} & \multirow[t]{2}{*}{$A \& B$} & \multirow[t]{2}{*}{$A \& B$} \\
\hline & & SA 447 GGAAGCTGCTITGGTAGATAC & & & & & $122+60$ & B & & & \\
\hline & \multirow{2}{*}{$\begin{array}{l}\text { DAZ-SNV_III } \\
(\text { (SY586) }\end{array}$} & SA 772 GTGTGGCACATATGCCTATAAA & \multirow[t]{2}{*}{ G63907 } & \multirow[t]{2}{*}{301} & \multirow[t]{2}{*}{ Taq1 } & \multirow[t]{2}{*}{$\mathrm{T} / \mathrm{CGA}$} & 301 & A & \multirow{2}{*}{$\begin{array}{c}2 \\
1,3,4\end{array}$} & \multirow[t]{2}{*}{$A \& B$} & \multirow[t]{2}{*}{$A \& B$} \\
\hline & & SA 773 TTGGTACATCCAGATGCAGAT & & & & & $184+117$ & B & & & \\
\hline \multirow{8}{*}{$\begin{array}{c}D A Z \\
\text { gene }\end{array}$} & \multirow[t]{2}{*}{ DAZ-SNV_IV } & SA 774 CTTCCTCATCTTTCTTGACTT & \multirow[t]{2}{*}{ G73168 } & \multirow[t]{2}{*}{630} & \multirow[t]{2}{*}{ Alul } & \multirow[t]{2}{*}{$\mathrm{AG} / \mathrm{CT}$} & 630 & A & \multirow{2}{*}{$\begin{array}{c}2 \\
1,3,4\end{array}$} & \multirow[t]{2}{*}{$A \& B$} & \multirow[t]{2}{*}{$A \& B$} \\
\hline & & SA 775 TTATTTATTCCTCAAAAAGGTG & & & & & $398+262$ & B & & & \\
\hline & DAZ-SNV_V & SA 444 TGGTTAATAAAGGGAAGGTGTTT & G63908 & 244 & Dral & TTT/AAA & $195+49$ & A & 3,4 & $A \& B$ & $A \& B$ \\
\hline & & SA 445 TCTCCAGGACAGGAAAATCC & & & & & $\begin{array}{c}122+73+ \\
49\end{array}$ & B & & & \\
\hline & DAZ-SNV_VI & SA 776 GGGCCTAGTCTCTAGATCATT & G73169 & 431 & AfIIII & $\mathrm{A} / \mathrm{CRYGT}$ & 431 & A & $1,2,3$ & $A \& B$ & A \\
\hline & & SA 777 GCTAGAACCAAATATTCTGGAT & & & & & $248+183$ & B & & & \\
\hline & DAZ-SNV_VII & SA 442 CACTGCCCTAATCCTAGCACA & G63906 & 252 & Sau3Al & /GATC & $189+63$ & A & 1,4 & $A \& B$ & $A \& B$ \\
\hline & & SA 443 TCTTCTGGACATCCACGTCA & & & & & $\begin{array}{c}130+63+ \\
59\end{array}$ & B & 2,3 & & \\
\hline GOLY1 & GOLY-SNV_1 & SA768 TTGGCCTGTTGCTTCTAGGGTT & BV012733 & 531 & Hhal & GCG/C & 531 & A & 1 Copy & $A \& B$ & $A \& B$ \\
\hline & & SA769 ACAGGGAGGGTGCTGTCACA & & & & & $289+282$ & B & 1 Copy & & \\
\hline BPY2 & BPY2 & SA766 AAGCCCATTGCTGAGATACTG & BV012732 & 470 & ECORV & GAT/ATC & 470 & A & 2 Copy & $A \& B$ & A \\
\hline & & SA767 TTGTGATTCTGACCCAACGA & & & & & $289+181$ & B & 1 Copy & & \\
\hline TTTY4 & TTTY4 & SA764 TGCAGACAGCACTGTGGCTT & BV012731 & 541 & Haell & $\mathrm{GG} / \mathrm{CC}$ & 541 & A & 1 Copy & $A \& B$ & $A \& B$ \\
\hline & & SA765 GTATATGGCATAATTTCACCTG & & & & & $323+218$ & B & 2 Copy & & \\
\hline
\end{tabular}


Table 3 List of primers used for PCR amplification of DYZ1 array (A) and SRY gene (B)

\begin{tabular}{|c|c|c|c|c|c|}
\hline \multicolumn{6}{|l|}{ (A) } \\
\hline Serial No. & Primer ID & Primer Sequence & Length (bp) & Location (DYZ1 array) & Orientation \\
\hline 1 & SAS 1 & CCATTCGAGACCGTAGCAAT & 20 & 35-16 (5' upstream to Haell site) & $5^{\prime}-3^{\prime}$ \\
\hline 2 & SAS 2 & TTTCCTTCGCTTGCATTCCAT & 22 & $63-84$ & $5^{\prime}-3^{\prime}$ \\
\hline 3 & SAS 3 & ATTTGATGCCATCCCATGAC & 20 & $763-782$ & $5^{\prime}-3^{\prime}$ \\
\hline 4 & SAS 4 & TITTGAGTCCGTTCCATAACAC & 22 & $1380-1401$ & $5^{\prime}-3^{\prime}$ \\
\hline 5 & SAS 5 & TCCTTGGCTTCCATTCG & 18 & $1668-1685$ & $5^{\prime}-3^{\prime}$ \\
\hline 6 & SAS 6 & TGCAGTCTITICCCTTCGAG & 20 & $2564-2583$ & $5^{\prime}-3^{\prime}$ \\
\hline 7 & SAS 7 & ATTGGATGGGATTGGAATGA & 20 & $861-880$ & $3^{\prime}-5^{\prime}$ \\
\hline 8 & SAS 8 & TGGATGGACTGCAATAGAAAG & 22 & $1600-1621$ & $3^{\prime}-5^{\prime}$ \\
\hline 9 & SAS 9 & TCGAATGGAAGGCAAAGG & 18 & $1669-1686$ & $3^{\prime}-5^{\prime}$ \\
\hline 10 & SAS 10 & CGACTGGTACGGACTCCAAT & 20 & $2637-2656$ & $3^{\prime}-5^{\prime}$ \\
\hline 11 & SAS 11 & GACTGGAAAGGCTGGGTGTCGA & 22 & $3419-3440$ & $3^{\prime}-5^{\prime}$ \\
\hline 12 & SAS 12 & TGGACAGCCTGGAATAAAGTG & 21 & $3586-3606$ & $3^{\prime}-5^{\prime}$ \\
\hline \multicolumn{6}{|l|}{ (B) } \\
\hline 1 & SA 531 & GAATCTGGTAGAAGTGAGTITGGA & 25 & $61-85$ & $5^{\prime}-3^{\prime}$ \\
\hline 2 & SA 532 & GCCTTTATTAGCCAGAGAAAAGAAA & 25 & $860-884$ & $3^{\prime}-5^{\prime}$ \\
\hline
\end{tabular}

Table 4 List of DYZ1 primer combinations used for end point PCR, their corresponding amplicon sizes and reaction conditions

\begin{tabular}{|c|c|c|c|}
\hline $\begin{array}{l}\text { Serial } \\
\text { No. }\end{array}$ & $\begin{array}{l}\text { DYZ1, Primer } \\
\text { Combinations }\end{array}$ & $\begin{array}{l}\text { Amplicon } \\
\text { Size (bp) }\end{array}$ & $\begin{array}{l}\text { PCR conditions (Annealing } \\
\text { and Extension) }\end{array}$ \\
\hline 1 & SAS (1\&7) & 915 & $64^{\circ} \mathrm{C}-1.0^{\prime}, 72^{\circ} \mathrm{C}-1.0^{\prime}$ \\
\hline 2 & SAS (1\&8) & 1656 & $65^{\circ} \mathrm{C}-1.0^{\prime}, 72^{\circ} \mathrm{C}-2.0^{\prime}$ \\
\hline 3 & SAS (1\&9) & 1721 & $61^{\circ} \mathrm{C}-1.0^{\prime}, 72^{\circ} \mathrm{C}-2.0^{\prime}$ \\
\hline 4 & SAS (2\&7) & 818 & $61^{\circ} \mathrm{C}-1.0^{\prime}, 72^{\circ} \mathrm{C}-1.0^{\prime}$ \\
\hline 5 & SAS (2\&8) & 1559 & $60-^{\circ} \mathrm{C} 1.0^{\prime}, 72^{\circ} \mathrm{C}-1.5^{\prime}$ \\
\hline 6 & SAS (3\&7) & 118 & $55^{-}{ }^{\circ} \mathrm{C} 1.0^{\prime}, 72^{\circ} \mathrm{C}-1.0^{\prime}$ \\
\hline 7 & SAS (3\&8) & 859 & $65^{\circ} \mathrm{C}-1.0^{\prime}, 72^{\circ} \mathrm{C}-1.0^{\prime}$ \\
\hline 8 & SAS (3\&9) & 924 & $61^{\circ} \mathrm{C}-1.0^{\prime}, 72^{\circ} \mathrm{C}-1.0^{\prime}$ \\
\hline 9 & SAS (3\&10) & 1894 & $64-^{\circ} \mathrm{C} 1.0^{\prime}, 72^{\circ} \mathrm{C}-2.0^{\prime}$ \\
\hline 10 & SAS (4\&8) & 242 & $61^{\circ} \mathrm{C}-1.0^{\prime}, 72^{\circ} \mathrm{C}-1.0^{\prime}$ \\
\hline 11 & SAS (4\&9) & 307 & $55^{\circ} \mathrm{C}-1.0^{\prime}, 72^{\circ} \mathrm{C}-1.0^{\prime}$ \\
\hline 12 & SAS (4\&10) & 1277 & $61^{\circ} \mathrm{C}-1.0^{\prime}, 72^{\circ} \mathrm{C}-1.5^{\prime}$ \\
\hline 13 & SAS (4\&11) & 2061 & $62^{\circ} \mathrm{C}-1.0^{\prime}, 72^{\circ} \mathrm{C}-2.5^{\prime}$ \\
\hline 14 & SAS (4\&12) & 2192 & $61^{\circ} \mathrm{C}-1.0^{\prime}, 72^{\circ} \mathrm{C}-2.5^{\prime}$ \\
\hline 15 & SAS (5\&10) & 989 & $61^{\circ} \mathrm{C}-1.0^{\prime}, 72^{\circ} \mathrm{C}-1.0^{\prime}$ \\
\hline 16 & SAS (5\&12) & 1904 & $61^{\circ} \mathrm{C}-1.0^{\prime}, 72^{\circ} \mathrm{C}-2.0^{\prime}$ \\
\hline 17 & SAS (6\&10) & 93 & $61^{\circ} \mathrm{C}-1.0^{\prime}, 72^{\circ} \mathrm{C}-1.0^{\prime}$ \\
\hline 18 & SAS (6\&11) & 877 & $61^{\circ} \mathrm{C}-1.0^{\prime}, 72^{\circ} \mathrm{C}-1.0^{\prime}$ \\
\hline 19 & SAS (6\&12) & 1008 & $64^{\circ} \mathrm{C}-1.0^{\prime}, 72^{\circ} \mathrm{C}-1.0^{\prime}$ \\
\hline
\end{tabular}

Additional file 2). The DYZ1 sequences from both DU145 and $\mathrm{LNCaP}$ cells were aligned with the reference sequence from NCBI database (Accession no. AC068123.5, Gene ID- 100499443) using ClustalW software (see Additional file 3). Between DU145 and the reference sequence; 23 point mutations, between DU145 and LNCaP; 11 point mutations and between LNCaP and the reference sequence; 27 point mutations were detected. Compared to the reference DYZ1 sequence, DU145 showed Insertion of $16 \mathrm{bp}$ in between the position of $1654^{-}$and $1655 \mathrm{bp}$, deletions of 1 bp at position 792 bp and 15 bp between $2606-$ 2622 position, respectively. LNCaP showed insertion of $15 \mathrm{bp}$ between 1654- 1655 bp position and deletion of 114 bp between 2541-2657 bp. The regions showing major deletions are given in Figure 6 (For complete details, please see Additional file 3). A comparison of LNCaP with DU145 showed a net deletion of $99 \mathrm{bp}$ in LNCaP. Upon virtual restriction mapping of $3.56 \mathrm{~Kb}$ unit of DYZ1 using Restriction Mapper version 3 software, loss and gain of several restriction sites were detected (Table 6). Compared to the reference sequence, a total of 6 restriction enzyme sites (BsaBI, NlaIV, BamHI, EcoRII, XhoII and CspCI) were lost and Eco57I site was gained in DU145. Similarly, a total 8 restriction enzyme sites (BsaBI, NlaIV, BamHI, EcoRII, XhoII, CspCI, MaeII and MaeIII) were lost and Eco57 site was gained in LNCaP. Thus, one Eco57I site was gained in both the cell lines. Differences in the restriction site frequency were compared amongst DU145, LNCaP and the reference sequence (Table 6). The result showed DYZ1 arrays are uniquely affected in each category of cells. 




Figure 4 Diagrammatic illustration showing end point PCR for the amplification of different sub-fractions of the DYZ1 array in DU145 and LNCaP cells. A single array of DYZ1 is shown on top. Forward and reverse primers are shown above and below the bars. Similarly, amplification products and their corresponding sizes are shown below. The fragments highlighted (dark bar) were used for subsequent cloning and sequencing analysis.

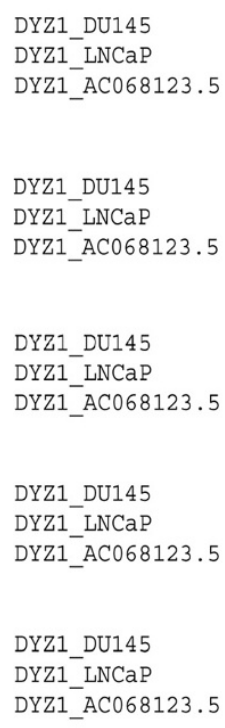

Figure 5 DYZ1 sequence showing insertion and deletion. Partial aligned DYZ1 sequence from DU145 and LNCaP showing insertion and deletion compared to that of the reference sequence AC068123.5. 
Table 5 Occurrence of "TTCCA" repeats and its derivatives with single or multiple base alterations per 3564 array of DYZ1 in DU145 and LNCaP with the reference sequence AC068123.5

\begin{tabular}{|c|c|c|c|c|}
\hline \multirow[t]{2}{*}{$\begin{array}{l}\text { Serial } \\
\text { No. }\end{array}$} & \multirow[t]{2}{*}{$\begin{array}{c}\text { Repeat unit } \\
\text { and derivatives }\end{array}$} & \multicolumn{3}{|c|}{$\begin{array}{c}\text { Number of TTCCA repeat units } \\
\text { and its derivatives per } 3564 \text { bpHaell } \\
\text { unit of DYZ1 array }\end{array}$} \\
\hline & & AC068123.5 & DU145 & LNCaP \\
\hline 1 & Actual Size (bp) & 3564 & 3564 & 3465 \\
\hline 2 & TTCCA & 229 & 235 & 228 \\
\hline 3 & 1 bp derivatives & 292 & 289 & 282 \\
\hline 4 & ATCCA & 11 & 9 & 9 \\
\hline 5 & TACCA & 3 & 3 & 2 \\
\hline 6 & TाACA & 14 & 13 & 15 \\
\hline 7 & TTCAA & 21 & 22 & 22 \\
\hline 8 & TाTCA & 19 & 19 & 19 \\
\hline 9 & ТTCTA & 25 & 25 & 25 \\
\hline 10 & ТТССТ & 32 & 33 & 33 \\
\hline 11 & GTCCA & 27 & 31 & 28 \\
\hline 12 & TGCCA & 9 & 10 & 10 \\
\hline 13 & TTGCA & 25 & 22 & 22 \\
\hline 14 & TTCGA & 60 & 60 & 57 \\
\hline 15 & TTCCG & 18 & 17 & 16 \\
\hline 16 & CTCCA & 14 & 14 & 14 \\
\hline 17 & TCCCA & 6 & 4 & 4 \\
\hline 18 & TTCCC & 8 & 7 & 6 \\
\hline 19 & 2 bp derivatives & 142 & 142 & 139 \\
\hline 20 & 3 bp derivatives & 37 & 33 & 30 \\
\hline 21 & 4 bp derivatives & 9 & 9 & 10 \\
\hline 22 & 5 bp derivatives & 1 & 1 & 1 \\
\hline
\end{tabular}

\section{FISH analysis}

The prostate cells DU145 might have encountered many changes including translocation of the part of 20th chromosome to the Y chromosome. The DU145 Y chromosome was found to harbour only 742 copies of DYZ1 which is far less than that in a normal Y chromosome. The DYZ1 constitutes approximately $20 \%$ of the normal human Y chromosome needed for the maintenance of its structural and functional integrities. A decrease in the number of arrays seems to threaten the survival of Y chromosome in DU145 cell. To ascertain the presence or the absence of Y chromosome in DU145 cells, we conducted FISH experiment using a labelled DYZ1 probe. Approximately, 400 nuclei and metaphases were screened. To rule out the possibility of experimental error, as a positive control, the metaphases from the normal human male were hybridized with DYZ1 probe. Several nuclei and metaphases in DU145 were found to be devoid of DYZ1 fluorescence signals. This way, approximately, $48 \%$ of DU145 cells were found to have no Y chromosome (Figure 7).

\section{Discussion}

DU145 and LNCaP cells originated from prostate tumours. Despite involvement of several chromosomes in the etiology of $\mathrm{PC}$, our focus remained on the $\mathrm{Y}$ chromosome of the two cell lines to assess several Y linked genes and DYZ1 regions. Sequences of the SRY gene were found to be normal in both the cells. Previous studies conducted on PC cell lines employed conventional G-banding, FISH, CGH and SKY approaches. However, these techniques owing to innate limitations, do not detect microdeletions. Despite 51 STSs encompassing $A Z F a, A Z F b$ and $A Z F c$ screened in this study, no microdeletions were detected suggesting that MSY remained intact in both the cell lines.

In an earlier report, $Y$ chromosome was excluded from the CGH analysis because of the presence of a large heterochromatic region [39]. In this study, we particularly focused on the heterochromatic region DYZ1 and assessed not only its copy number variation but also indels all along the length of the array. We detected 742 copies in DU145 and that of 1945 in LNCaP cells. Significant difference in the copy number of DYZ1 between DU145 and LNCaP could be due to the unequal number of Y chromosome(s) per cell. It may be noted that DU145 carries single $Y$ chromosome per cell coupled with a major translocation of part of 20th chromosome to the Y chromosome, whereas LNCaP carries $2 \mathrm{Y}$ chromosomes per cell [3]. In an earlier study on the biopsied samples of PC, we detected 550 copies of the DYZ1 [26] which is in accordance with our present study.

Though MSY was intact in DU145 and LNCaP cells but DYZ1 was clearly affected showing insertion, deletion, frequent point mutations and copy number variations. These mutational events, not only shifts the frame of abundant "TTCCA" repeats but also generate its derivatives leading to the shrinkage or expansion of the same. The insertion and deletion of $16 \mathrm{bp}$ kept the frame unchanged and maintained the original length of array of 3564 bp in DU145. Due to insertion of 15 bp and deletion of $114 \mathrm{bp}$, the LNCaP cells showed net loss of $99 \mathrm{bp}$ in the array of $3564 \mathrm{bp}$ (Additional file 3). A normal array of 3564 bp harbours approximately 80 different restriction enzyme recognition sites [25]. We detected more loss of restriction sites in both the cell lines than that of their gains. Startlingly, a single Eco57I site was gained in both the cell types though its biological significance remained unclear. These results clearly suggest that DYZ1 is indeed affected during the process of cells becoming cancerous. Despite these changes, Y chromosome survived in about 58\% of DU145 cells (Figure 7). Most likely, such DU145 cells have managed to retain the critical number 


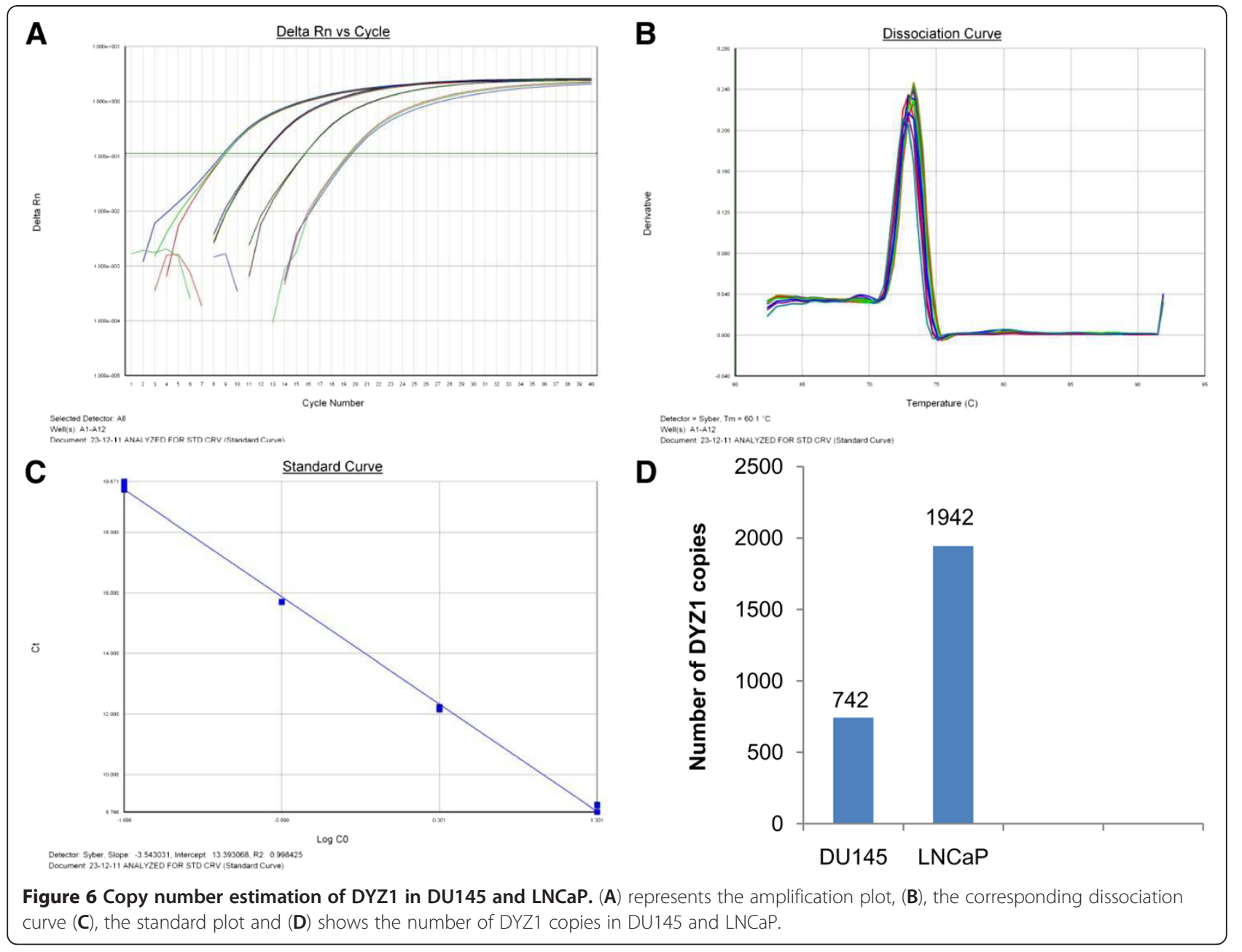

of the DYZ1 copies with near normal sequences needed for the sustenance of the $Y$ chromosome.

The African-American men have been found to show highest and Japanese, the lowest incidences of PC in the world [40-42]. This suggests that males from different ethnicity and geographical regions may be different with respect to their susceptibility to develop prostate cancer. It may be noted that status of DYZ1 was not assessed in the males from either of these populations. Based on our study, we presume that besides susceptibility to PC, males from different ethnic and geographical regions may show sequence and copy number variations in the DYZ1 arrays. However, this warrants a detailed analysis of sufficient number of PC males before a conclusion can be drawn. When, once this issue is fully resolved, DYZ1 may be added amongst the list of possible bio-marker for DNA based diagnosis using PC biopsied samples.

\section{Conclusions}

Our study demonstrates that, MSY region and SRY gene both remain intact in DU145 and LNCaP PC cell lines. Since, DYZ1 region is maximally affected both in terms of sequence and array's copy number; this may be exploited as possible bio-marker for DNA based diagnosis of PC together with other marker systems.

\section{Methods}

\section{Cell culture and DNA isolation}

DU145 and LNCaP cell lines were available with National Institute of Immunology, New Delhi and Jawaharlal Nehru University, New Delhi, respectively in connection with other projects. Institute and University procured this cell lines from ATCC (American Type Culture Collection, Manassas, USA). DU145 cells were cultured in T75 flasks containing 10\% DMEM (Dulbecco's Modified Eagle Medium, Life Technologies, Gibco, USA). LNCaP cells were cultured in T75 flask containing 10\% RPMI 1640 (Life Technologies, Gibco, USA). Cultures were supplemented with $1 \%$ antibiotic and antimycotic solution.

DNA from cultured cells was isolated using DNeasy Blood and Tissue kit (Qiagen, Germany). Quality of isolated DNA was checked by electrophoresis using $1 \%$ agarose gel and concentration was measured spectrophotometrically. 
Table 6 Restriction mapping of 3.56 Kb DYZ1 sequence from DU145, LNCaP and the reference sequence AC068123.5 by virtual digest using Restriction Mapper Version 3 software

\begin{tabular}{|c|c|c|c|c|c|c|c|}
\hline \multirow{2}{*}{$\begin{array}{c}\text { Serial } \\
\text { No. }\end{array}$} & \multirow{2}{*}{$\begin{array}{l}\text { Restriction } \\
\text { enzyme }\end{array}$} & \multirow[t]{2}{*}{ Sequence } & \multirow{2}{*}{$\begin{array}{l}\text { Sight } \\
\text { Length }\end{array}$} & \multirow[t]{2}{*}{ Overhung } & \multicolumn{3}{|c|}{ Frequency of cut sites } \\
\hline & & & & & AC068123.5 & DU145 & LNCaP \\
\hline 1 & BsaBl & GATNNNNATC & 6 & blunt & 1 & 0 & 0 \\
\hline 2 & Cac8l & GCNNGC & 4 & blunt & 1 & 1 & 1 \\
\hline 3 & NlalV & GGNNCC & 4 & blunt & 1 & 0 & 0 \\
\hline 4 & BamHI & GGATCC & 6 & $5^{\prime}$ & 1 & 0 & 0 \\
\hline 5 & BseYl & CCCAGC & 6 & $5^{\prime}$ & 1 & 1 & 1 \\
\hline 6 & Bsp1407| & TGTACA & 6 & $5^{\prime}$ & 1 & 1 & 1 \\
\hline 7 & $\mathrm{BspHI}$ & TCATGA & 6 & $5^{\prime}$ & 1 & 1 & 1 \\
\hline 8 & Clal & ATCGAT & 6 & $5^{\prime}$ & 1 & 1 & 1 \\
\hline 9 & Ddel & CTNAG & 4 & $5^{\prime}$ & 1 & 1 & 1 \\
\hline 10 & EcoRl & GAATTC & 6 & $5^{\prime}$ & 1 & 1 & 1 \\
\hline 11 & EcoRII & CCWGG & 5 & $5^{\prime}$ & 1 & 0 & 0 \\
\hline 12 & Maell & ACGT & 4 & $5^{\prime}$ & 1 & 1 & 0 \\
\hline 13 & Maelll & GTNAC & 4 & $5^{\prime}$ & 1 & 1 & 0 \\
\hline 14 & Vspl & ATTAAT & 6 & $5^{\prime}$ & 1 & 1 & 1 \\
\hline 15 & Xholl & RGATCY & 6 & $5^{\prime}$ & 1 & 0 & 0 \\
\hline 16 & BseMII & CTCAG & 5 & $3^{\prime}$ & 1 & 1 & 1 \\
\hline 17 & $B s g l$ & GTGCAG & 6 & $3^{\prime}$ & 1 & 1 & 1 \\
\hline 18 & $B t s \mid$ & GCAGTG & 6 & $3^{\prime}$ & 1 & 1 & 1 \\
\hline 19 & Eco57l & CTGAAG & 6 & $3^{\prime}$ & 0 & 1 & 1 \\
\hline 20 & Eco57Ml & CTGRAG & 6 & $3^{\prime}$ & 1 & 2 & 2 \\
\hline 21 & Gsul & CTGGAG & 6 & $3^{\prime}$ & 1 & 1 & 1 \\
\hline 22 & Нру1881 & TCNGA & 4 & $3^{\prime}$ & 1 & 1 & 1 \\
\hline 23 & Mnll & ССТC & 4 & $3^{\prime}$ & 1 & 1 & 1 \\
\hline 24 & PfIMl & CCANNNNNTGG & 6 & $3^{\prime}$ & 1 & 1 & 1 \\
\hline 25 & Sdul & GDGCHC & 6 & $3^{\prime}$ & 1 & 1 & 1 \\
\hline 26 & $\mathrm{ScrFI}$ & CCNGG & 4 & $5^{\prime}$ & 2 & 1 & 1 \\
\hline 27 & Arsl & GACNNNNNNTTYG & 7 & $3^{\prime}$ & 2 & 2 & 2 \\
\hline 28 & Bdal & TGANNNNNNTCA & 6 & $3^{\prime}$ & 2 & 2 & 2 \\
\hline 29 & CspCl & CAANNNNNGTGG & 7 & $3^{\prime}$ & 2 & 0 & 0 \\
\hline 30 & TspRI & CASTG & 5 & $3^{\prime}$ & 2 & 2 & 2 \\
\hline 31 & Dpnl & GATC & 4 & blunt & 3 & 2 & 2 \\
\hline 32 & Apol & RAATTY & 6 & $5^{\prime}$ & 3 & 3 & 3 \\
\hline 33 & Asull & TTCGAA & 6 & $5^{\prime}$ & 3 & 3 & 3 \\
\hline 34 & Eco311 & GGTCTC & 6 & $5^{\prime}$ & 3 & 2 & 2 \\
\hline 35 & Mael & CTAG & 4 & $5^{\prime}$ & 3 & 3 & 4 \\
\hline 36 & $\mathrm{Mbol}$ & GATC & 4 & $5^{\prime}$ & 3 & 2 & 2 \\
\hline 37 & SfaNl & GCATC & 5 & $5^{\prime}$ & 3 & 4 & 4 \\
\hline 38 & Tatl & WGTACW & 6 & $5^{\prime}$ & 3 & 3 & 3 \\
\hline 39 & Setl & ASST & 4 & $3^{\prime}$ & 3 & 3 & 1 \\
\hline 40 & Cvill & RGCY & 4 & blunt & 4 & 4 & 4 \\
\hline 41 & Msll & CAYNNNNRTG & 6 & blunt & 4 & 4 & 4 \\
\hline 42 & Fokl & GGATG & 5 & $5^{\prime}$ & 4 & 2 & 2 \\
\hline
\end{tabular}


Table 6 Restriction mapping of 3.56 Kb DYZ1 sequence from DU145, LNCaP and the reference sequence AC068123.5 by virtual digest using Restriction Mapper Version 3 software (Continued)

\begin{tabular}{|c|c|c|c|c|c|c|c|}
\hline 43 & Alfl & GCANNNNNNTGC & 6 & $3^{\prime}$ & 4 & 4 & 4 \\
\hline 44 & Rsal & GTAC & 4 & blunt & 5 & 5 & 4 \\
\hline 45 & $B C C l$ & CCATC & 5 & $5^{\prime}$ & 5 & 3 & 4 \\
\hline 46 & BsmAl & GTCTC & 5 & $5^{\prime}$ & 5 & 5 & 4 \\
\hline 47 & Msel & TTAA & 4 & $5^{\prime}$ & 5 & 6 & 6 \\
\hline 48 & BstXI & CCANNNNNNTGG & 6 & $3^{\prime}$ & 5 & 5 & 4 \\
\hline 49 & Mboll & GAAGA & 5 & $3^{\prime}$ & 5 & 3 & 3 \\
\hline 50 & $x m n l$ & GAANNNNTTC & 6 & blunt & 6 & 6 & 6 \\
\hline 51 & Tstl & CACNNNNNNTCC & 6 & $3^{\prime}$ & 6 & 4 & 4 \\
\hline 52 & Nlalll & CATG & 4 & $3^{\prime}$ & 7 & 7 & 7 \\
\hline 53 & $B c g l$ & CGANNNNNNTGC & 6 & $3^{\prime}$ & 16 & 14 & 14 \\
\hline 54 & BsrDl & GCAATG & 6 & $3^{\prime}$ & 16 & 14 & 14 \\
\hline 55 & $B s r l$ & ACTGG & 5 & $3^{\prime}$ & 17 & 19 & 18 \\
\hline 56 & TspGWl & ACGGA & 5 & $3^{\prime}$ & 20 & 23 & 17 \\
\hline 57 & Agsl & TTSAA & 5 & $3^{\prime}$ & 22 & 20 & 23 \\
\hline 58 & Bsml & GAATGC & 6 & $3^{\prime}$ & 22 & 23 & 21 \\
\hline 59 & Fail & YATR & 4 & blunt & 23 & 25 & 23 \\
\hline 60 & Plel & GAGTC & 5 & $5^{\prime}$ & 23 & 21 & 21 \\
\hline 61 & TspDTI & ATGAA & 5 & $3^{\prime}$ & 25 & 24 & 24 \\
\hline 62 & TspEI & AATT & 4 & $5^{\prime}$ & 35 & 35 & 35 \\
\hline 63 & Tfil & GAWTC & 5 & $5^{\prime}$ & 52 & 51 & 51 \\
\hline 64 & Taql & TCGA & 4 & $5^{\prime}$ & 66 & 62 & 62 \\
\hline 65 & Hinfl & GANTC & 4 & $5^{\prime}$ & 75 & 72 & 72 \\
\hline
\end{tabular}

The loss or gains of the restriction sites with respect to the reference sequence are highlighted in bold.

\section{Sequence Tagged Site (STS) mapping of MSY region}

MSY region was analysed for micro-deletions using STS end point PCR reactions. A total of 51 STSs were selected from the MSY breakpoint mapper for screening this region. The end point PCR reactions were performed in $20 \mu \mathrm{l}$ reaction volumes containing $5 \mathrm{X}$ Green Go Taq reaction buffer (Promega, Madison, USA), $200 \mu \mathrm{M}$ dNTPs (Biotools, Spain), 1 IU Go Taq polymerase (Promega, Madison, USA) and $100 \mathrm{ng}$ of genomic DNA. STS PCR primers were procured from Sigma-Aldrich, USA. STS screening was performed following the PCR conditions available in MSY Breakpoint Mapper database [17]. $\beta$-actin (Forward primer- 5' AGATGACCCAGATCATGTTTGA GA 3' and Reverse primer- 5' CTAAGTCATAGTCCGCC TAGAAGC) and sY14 (Additional file 4) primers were used as control for assessing the quality of genomic DNA. Genomic DNA from normal males were used as positive controls. Female genomic DNA and a reaction without template were used as negative controls. The amplified products were resolved on 1.5\% agarose gel, stained with ethidium bromide and visualized under UV illumination.

\section{Single Nucleotide Variants (SNV) analysis}

The $A Z F C$ region of MSY was analyzed for $7 \mathrm{SNVs}$ in the $D A Z$ region and one SNV for GOLY1, BPY2 and TTTY4 by PCR-restriction fragment length polymorphism. The details of primer sequences, accession numbers, product sizes and restriction enzymes used for SNV analysis are given in the Table 2. SNV PCR reactions were performed in $40 \mu \mathrm{l}$ following standard PCR conditions. The amplified PCR product was precipitated by addition of $4 \mu \mathrm{l}$ of $3 \mathrm{M}$ sodium acetate and $120 \mu \mathrm{l}$ of absolute ethanol and incubated at $-70^{\circ} \mathrm{C}$ for 4 hours. DNA was pelleted down at 13,000 rpm for 20 minutes at $4^{\circ} \mathrm{C}$, washed in $70 \%$ ethanol, dried and dissolved in $10 \mu \mathrm{l}$ water. The purified PCR products were further subjected to restriction digestion using appropriate restriction enzymes and buffer. The digested fragments were resolved on $2.5 \%$ agarose gel, stained with ethidium bromide and visualized under UV illumination.

\section{Cloning and sequencing of $S R Y$ and DYZ1 array}

Pfu DNA polymerase (Biotools, Spain) amplified amplicons were resolved on $1.5 \%$ agarose gel, sliced and eluted using 


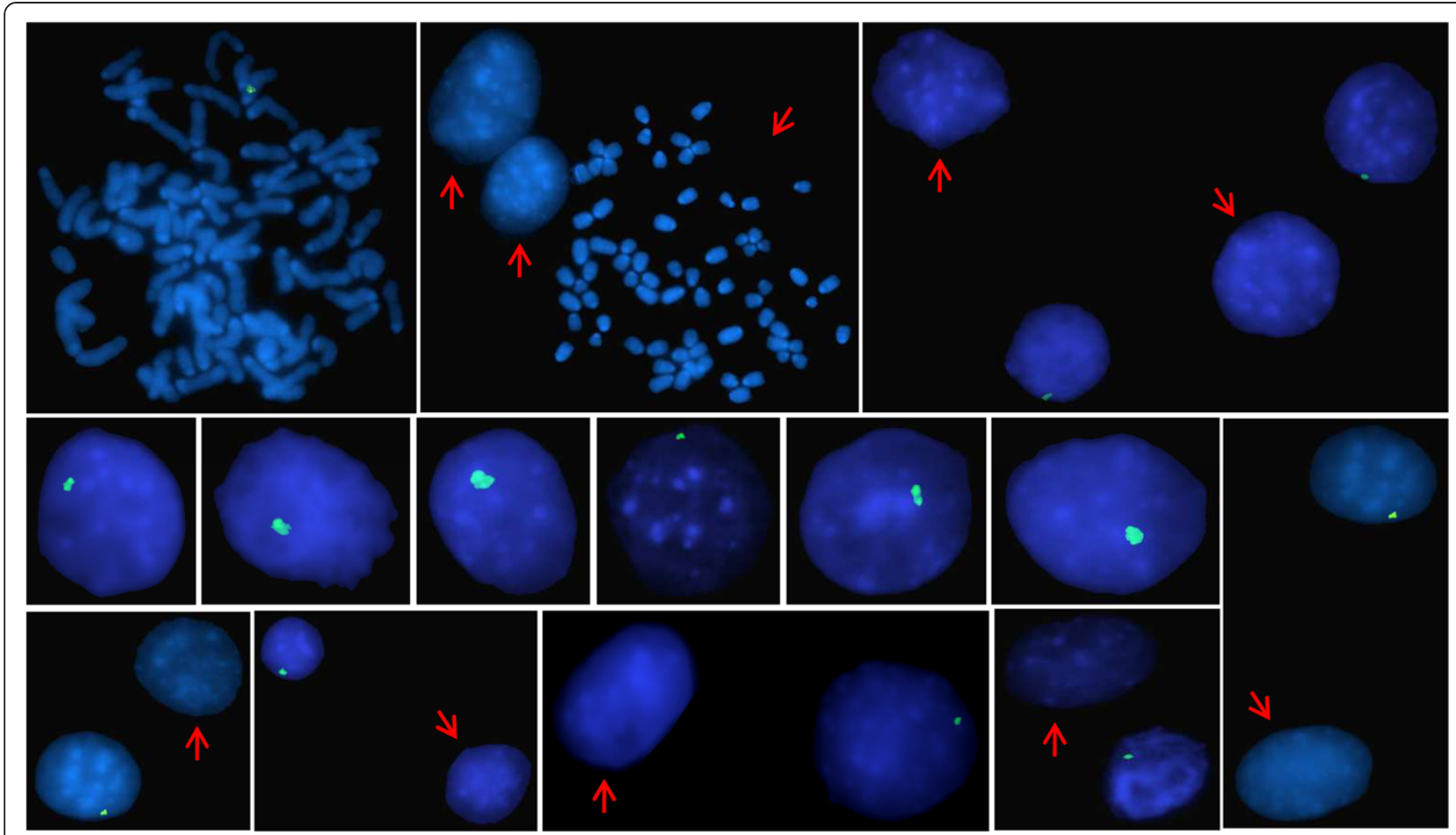

Figure 7 Localization of DYZ1 in DU145 cells by FISH. DAPI (4', 6-diamidino-2-phenylindole) stained metaphases and interphase nuclei are shown having green signal of DYZ1. Nuclei and metaphases lacking DYZ1 are indicated by red arrow. Note the variation in the DYZ1 signal intensities across nuclei reflecting copy number variation.

gel extraction kit (Fermentas, Thermo Fischer Scientific). Eluted DNA was cloned in $\mathrm{pGEM}^{-} \mathrm{T}$ easy vector (Promega, Madison, USA). 4 recombinant clones for each fragment were sequenced on Applied Biosystems 3130xl Genetic Analyzer using ABI PRISM $^{\bullet}$ BigDye $^{\bullet}$ terminator v3.1 cycle sequencing kit (Life Technologies, California, USA). For cycle sequencing, PCR reactions were set as $96^{\circ} \mathrm{C}$ for 1 minute, followed by 25 cycles each consisting of $96^{\circ} \mathrm{C}$ for 10 seconds, $50^{\circ} \mathrm{C}$ for 5 seconds, and $60^{\circ} \mathrm{C}$ for 4 minutes. After PCR, extension products were purified using ethanol-sodium acetate precipitation method followed by washing in $70 \%$ ethanol. $\mathrm{Hi}-\mathrm{Di}^{\mathrm{TM}}$ Formamide (Life Technologies, California, USA) was added, samples were heat denatured, chilled on ice and loaded on ABI 3130xl genetic analyzer. Sequencing was performed using Run 3130xl Data Collection software v3.0, sequences were retrieved using Sequencing Analysis 5.3.1 and sequence analysis was done using Gene runner software.

\section{Analysis of DYZ1 array}

The intactness of DYZ1 array was assessed using end point PCR. The details of primers, their combinations and PCR conditions are listed in the Table 4. Copy number of DYZ1 was calculated based on absolute quantification method using qPCR. DNA was used as template and SYBR green (Life Technologies, California, USA) was used as detection dye. The $\mathrm{qPCR}$ reactions were performed on Sequence Detection System 7500 (Life Technologies, California, USA). 10 fold dilutions of recombinant plasmid containing $\sim 3.56 \mathrm{~Kb}$ HaeIII fragment of DYZ1 array were used to generate standard curve starting with $2 \times 10^{8}$ copies. All the reactions were carried out in triplicates using three different concentrations of the template DNA from DU145 and LNCaP cells. The standard curve had a slope of -3.32 and $R^{2}$ value of $>0.99$. Copies of the DYZ1 array were calculated by extrapolation of the standard curve obtained with known copies of the recombinant plasmid.

\section{Florescence in-situ hybridization (FISH)}

DU145 cells cultured in 10\% DMEM were used for metaphase chromosome preparation. These cells were grown for 70 hours in $5 \% \mathrm{CO}_{2}$ environment at $37^{\circ} \mathrm{C}$ and then treated with colcemid $(3 \mu \mathrm{g} / \mathrm{ml})$. Treated cells were again incubated for 2 hours in $5 \% \mathrm{CO}_{2}$ environment at $37^{\circ} \mathrm{C}$. After 72 hours, cells were centrifuged at $1800 \mathrm{rpm}$ for 10 minutes at room temperature (RT). Harvested cells were resuspended in $0.075 \mathrm{M} \mathrm{KCl}$ and incubated at RT for 20 minutes in $5 \% \mathrm{CO}_{2}$ environment at $37^{\circ} \mathrm{C}$. Then added 1 drop of fixative solution (3:1, methanol: glacial acetic acid) and centrifuged at $1800 \mathrm{rpm}$ for $10 \mathrm{mi}-$ nutes at RT. Discarded the supernatant, resuspended the cell pellet in $10 \mathrm{ml}$ fresh fixative solution and incubated 
for 20 minutes at $37^{\circ} \mathrm{C}$. Then centrifuged cells at $1800 \mathrm{rpm}$ for 10 minutes at RT. Repeated the washing step 2 times. Finally, cells were resuspended in fresh $1 \mathrm{ml}$ fixative and stored at $-20^{\circ} \mathrm{C}$.

For metaphase chromosome preparation, $20 \mu \mathrm{l}$ of nuclei suspension in fixative was spread on the glass slides. Before proceeding further, slides were kept for 1 week at $37^{\circ} \mathrm{C}$ for ageing. Slides were then incubated in $70 \%$ glacial acetic acid for 2 minutes followed by dehydration in $70 \%, 90 \%$ and $100 \%$ ethanol for 2 minutes each at RT. Air dried the glass slides and incubated in a solution containing $0.1 \mathrm{mg} / \mathrm{ml}$ and $0.01 \mathrm{~N} \mathrm{HCl}$ for 20 minutes. Fixed the metaphase preparation in $4 \%$ paraformaldehyde (prepared in 1X PBS, pH 7.4) for 5 minutes at RT. Slides were then washed in 1.0 M Tris- $\mathrm{HCl}(\mathrm{pH} 7.4)$ followed by 2 washes in $1 \mathrm{X}$ phosphate buffer saline (PBS) for 5 minutes each at RT. Further, incubated in $0.5 \%$ Triton-X-100 (prepared in $1 \mathrm{X}$ PBS) for 10 minutes followed by 3 washes in 1X PBS for 5 minutes each. Slides were then incubated in $0.1 \mathrm{~N} \mathrm{HCl}$ for 10 minutes followed by 3 washes in $1 \mathrm{X}$ PBS for 5 minutes each and stored in $2 \mathrm{X} \mathrm{SSC} \mathrm{(pH} \mathrm{7.4)} \mathrm{overnight} \mathrm{at} 4^{\circ} \mathrm{C}$ until used for hybridization. FISH was conducted with a labelled clone containing $3.56 \mathrm{~kb}$ sequence of DYZ1. Labelling was done with biotin-dUTP using a Nick translation kit from Vysis (Illinois, USA). Hybridization, washing, counterstaining and mounting of the slides were conducted following standard protocols [43]. The slides were screened under the Olympus fluorescence microscope (BX 51) fitted with vertical fluorescence illuminator U-LH100HG UV, excitation and barrier filters and images were captured with a charge-coupled device (CCD) camera. Captured images were analyzed using CytoVision software version 3.93 from Applied Imaging Systems.

\section{Additional files}

Additional file 1: Multiple Sequence Alignment (MSA) of the SRY gene cloned and sequenced from DU145 and LNCaP with that of normal sequence (Accession number- NM_003140) in the database. Coding region starts at $89^{\text {th }} \mathrm{bp}$ and ends at $703 \mathrm{bp}$. MSA showed no sequence alteration within the SRY gene.

Additional file 2: Complete $3.56 \mathrm{~Kb}$ DYZ1 sequences of the reference sequence AC068123.5 (A), DU145 (B), and LNCaP (C), all showing in frame arrangement of the pentanucleotide motifs.

Additional file 3: Multiple Sequence Alignment of $3.56 \mathrm{~Kb}$ sequence of DYZ1 array from DU145 and LNCaP with sequence from the NCBI database (Accession no. AC068123.5, Gene ID100499443). Perfectly aligned sequences are indicated by star and deletions, by hyphens. Mismatched base pairs, deletions or insertions are highlighted in green colour.

Additional file 4: Details of STS primers used for screening MSY region.

\section{Abbreviations}

PC: Prostate cancer; STS: Sequence tagged site; NRY: Non recombining region of Y; MSY: Male specific region of Y; FISH: Fluorescence in situ hybridization; CGH: Comparative genomic hybridization; SKY: Spectral karyotyping; SNV: Single nucleotide variants; DNA: Deoxyribonucleic acid; UV: Ultraviolet; PCR: Polymerase chain reaction; qPCR: Quantitative polymerase chain reaction.

\section{Competing interests}

The authors declare that they have no competing interests.

\section{Authors' contribution}

SKY and AK carried out the experiments. SKY did in-silico analysis, interpreted the data and wrote the manuscript. SA conceived the study, interpreted the results, revised the manuscript critically and provided overall supervision. All the authors read and approved the final manuscript.

\section{Acknowledgements}

This work was supported by the Department of Biotechnology, Government of India Grant - BT/PR1 1805/MED/12/424/2009 and BT/PR14102/AAQ/01/438/ 2010 to SA and a core grant from DBT, New Delhi to the National Institute of Immunology, New Delhi. SA is also grateful to Department of Science and Technology, New Delhi, Government of India, for J. C. Bose National Fellowship. The authors also acknowledge the Council of Scientific and Industrial Research (CSIR), New Delhi, for its financial assistance to SKY and AK as Senior Research Fellow (SRF). The funders had no role in study design, data collection; analysis and interpretation, preparation of the manuscript or decision to publish. We thank Dhanya, Abhinaya T. Sundari and Shri Khem Singh Negi for their technical assistance. Equipment donation from the Alexander Von Humboldt Foundation, Bonn, Germany is gratefully acknowledged. Authors declare no conflicts of interest regarding submitted manuscript.

Received: 12 February 2013 Accepted: 7 May 2013

Published: 11 May 2013

\section{References}

1. Ewis AA, Lee J, Naroda T, Sano T, Kagawa S, Iwamoto T, Shinka, Shinohara $Y$, Ishikawa M, Baba Y, Nakahori Y: Prostate cancer incidence varies among males from different Y-chromosome lineages. Prostate Cancer Prostatic Dis 2006, 9(3):303-309.

2. Parkin DM, Pisani P, Ferlay J: Estimates of the worldwide incidence of 25 major cancers in 1990. Int J Cancer 1990, 80(6):827-841.

3. Pan Y, Kytölä S, Farnebo F, Wang N, Lui WO, Nupponen N, Isola J, Visakorpi T, Bergerhein USR, Larsson C: Characterization of chromosomal abnormalities in prostate cancer cell lines by Spectral Karyotyping. Cytogenet Cell Genet 1999, 87(3-4):225-232.

4. Tribukait B: DNA flow cytometry in carcinoma of the prostate for diagnosis, prognosis and study of tumour biology. Acta Oncol 1991, 30(2):187-192.

5. Visakorpi T, Kylmala T, Tainio H, Hoivula T, Tammela T, Isola J: High cell proliferation activity determined by DNA flow cytometry predicts poor prognosis after relapse in prostate cancer. Eur J Cancer 1994, 30A(1):129-130.

6. Isaacs WB: Molecular Genetics of prostate cancer. Cancer Surv 1995, 25:357-379.

7. Kallioniemi OP, Visakorpi T: Genetic basis and clonal evolution of human prostate cancer. Adv Cancer Res 1996, 68:225-255.

8. Vijaykumar S, Gracia D, Hensel DH, Banerjee M, Bracht T, Xianq R, Kaqan J, Naylor SL: The human Y chromosome suppresses the tumorigenicity of PC-3, a human prostate cancer cell line in Athymic Nude Mice. Genes Chromosomes Cancer 2005, 44(4):365-372.

9. Van $\mathrm{DH}$, Alers J: Loss of chromosome $\mathrm{Y}$ in prostatic Cancer cells but not in stromal tissues. Cancer Genet Cytogenet 1993, 66(2):131-132.

10. Ewis AA, Lee J, Naroda J, Sasahara K, Sano T, Kagawa S, Iwamoto T, Nakahor $Y$ : Prostate cancer incidence and different alleles of the human Y-linked tetranucleotide polymorphism DYS 19. J Med Invest 2002, 49(1-2):56-60.

11. Paracchini C, Pearce CL, Kolonel LN, Altshuler D, Henderson BE: A Y chromosomal influence on prostate cancer risk: the multi-ethnic cohort study. J Med Genet 2003, 40(11):815-819.

12. Kim W, Yoo TK, Kim SJ, Shin DJ, Tyler-Smith C, Jin HJ, Kwak KD, Kim ET, Bae YS: Lack of association between Y-chrmosomal haplogroups and prostate cancer in the Korean population. PLoS One 2007, 2(1):e172.

13. Lau YFC, Zhang J: Expression analysis of thirty one $Y$ chromosome genes in human prostate cancer. Mol Carcinog 2000, 27(4):308-321. 
14. Dasari VK, Goharderakhshan RZ, Perinchery G, Li LC, Tanaka Y, Alonzo J, Dahiya R: Expression analysis of $Y$ chromosome genes in human prostate cancer. J Urol 2001, 165(4):1335-1341.

15. Yuan X, Lu ML, Li T, Balk SP: SRY interacts with and negatively regulates androgen receptor transcriptional activity. J Biol Chem 2001, 276(49):46647-4654.

16. Tricoli JV, Yao JL, D'souza SA, Bracken RB: Detection of sex-region Y (SRY) transcripts in human prostate adenocarcinoma and benign prostatic hypertrophy. Genes Chromosomes Cancer 1993, 8(1):28-33.

17. Lange J, Skaletsky H, Bell GW, Page DC: MSY breakpoint mapper, a database of sequence-tagger sites useful in defining naturally occurring deletions in the human Y chromosome. Nucleic Acids Res 2008, 36:D809-D814.

18. Konig JJ, Teubel W, Kamst E, Romijn JC, Schroder FH, Hagemeijer A: Cytogenetic analysis of 39 prostate carcinomas and evaluation of shortterm tissue culture techniques. Cancer Genet Cytogenet 1998, 101(2):116-122.

19. Pinkel D, Straume T, Gray J: Cytogenetic analysis using quantitative, high sensitive, fluorescence in situ hybridization. Proc Natl Acad Sci USA 1986, 83(9):2934-2938.

20. Kallioniemi A, Kallioniemi OP, Sudar D, Rotovitz D, Gray JW, Waldman F, Pinkel D: Comparative genomic hybridization for molecular cytogenetic analysis of solid tumors. Science 1992, 258(5083):818-821.

21. Speicher MR, Ballard SG, Ward DC: Karyotyping human chromosome by combinatorial multi-fluor FISH. Nat Genet 1996, 12(4):368-375.

22. Schrock E, du Manior S, Veldman T, Schoell B, Wienberg J, Ferguson-Smith MA, Ning Y, Ledbetter DH, Bar-Am I, Soenksen D, Garini Y, Ried T: Multicolor spectral karyotyping of human chromosome. Science 1996, 273(5274):494-497.

23. Gibas Z, Becher R, Kawinski E, Horoszewicz J, Sandyberg AA: A high resolution study of chromosome changes in a human prostatic carcinoma cell line (LNCaP). Cancer Genet Cytogenet 1984, 11(4):399-404.

24. Ali S, Husnain SE: Genomics of the human Y-chromosome: association with male infertility. Gene 2003, 4(321):25-37.

25. Nakahori $Y$, Mitani $K$, Yamada M, Nakgome $Y$ : A human $Y$ chromosome specific repeated DNA family (DYZ1) consists of a tandem array of pentanucleotides. Nucleic Acids Res 1986, 14(19):7569-7580.

26. Pathak D, Premi S, Srivastava J, Chandy SP, Ali S: Genomic instability of the DYZ1 repeat in patients with $Y$ chromosome anomalies and males exposed to Natural Background Radiation. DNA Res 2006, 13(3):103-109.

27. Lahn BT, Pearson NM, Jegalian K: The human $Y$ chromosome in the light of evolution. Nat Rev Genet 2001, 2(3):207-216.

28. Sun C, Skaletsky H, Rozen S, Gromoll J, Nieschlag E, Oates R, Page DC: Deletion of the Azoospermia factor a $(A Z F a)$ region of human $Y$ chromosome caused by recombination between HERV 15 proviruses. Hum Mol Genet 2000, 9(15):2291-2296.

29. Kamp C, Hirschmann P, Voss H, Huellen K, Vogt PH: Two long homologous retroviral sequence blocks in proximal Yq11 cause AZFa microdeletions as a result of intrachromosomal recombination events. Hum Mol Genet 2000, 9(17):2563-2572.

30. Blanco P, Shlumukova M, Sargent CA, Jobling MA, Affara N, Hurles ME: Divergent outcomes of intrachromosomal recombination on the human Y chromosome: male infertility and recurrent polymorphism. J Med Genet 2000, 37(10):752-758

31. Repping S, Skaletsky H, Lange J, Silber S, van der Veen F, Oates RD, Page DC, Rozen S: Recombination between palindromes P5 and P1 on the human $Y$ chromosome causes massive deletions and spermatogenic failure. Am J Hum Genet 2002, 71(4):906-922.

32. Repping S, Skaletsky H, Brown L, van Daalen SK, Korver CM, Pyntikova T, Kuroda-Kawaguchi T, de Vries JW, Oates RD, Silber S, van der Veen F, Page DC, Rozen S: Polymorphism for a 1.6-Mb deletion of the human $Y$ chromosome persists through balance between recurrent mutation and haploid selection. Nat Genet 2003, 35(3):247-251.

33. Repping S, van Daalen SK, Korver CM, Brown LG, Marszalek JD, Geanotten J, Oates RD, Silber S, van der Veen F, Page DC, Rozen S: A family of human Y chromosomes has dispersed throughout northern Eurasia despite a 1.8-Mb deletion in the azoospermia factor c region. Genomics 2004, 83(6):1046-1052.

34. Kuroda-Kawaguchi T, Skaletsky H, Brown LG, Minx PJ, Cordum HS, Waterston RH, Wilson RK, Silber S, Oates R, Rozen S, Page DC: The AZFC region of the $Y$ chromosome features massive palindromes and uniform recurrent deletions in infertile men. Nat Genet 2001, 29(3):279-286.

35. Fernandes S, Paracchini S, Meyer LH, Floridia G, Tyler- Smith C, Vogt PH: A large $A Z F C$ deletion removes $D A Z 3 / D A Z 4$ and nearby genes from men in Y haplogroup N. Am J Hum Genet 2004, 74(1):180-187.
36. Jobling MA, Lo IC, Turner DJ, Bowden GR, Lee AC, Xue Y, Carvalho-Silva D, Hurles ME, Adams SM, Chang YM, Kraaijenbrink T, Henke J, Guanti G, McKeown B, van Oorschot RA, Mitchell RJ, De knijff P, Tyler-Smith C, Parkin EJ: Structural variation on the short arm of the human $Y$ chromosome: recurrent multigene deletions encompassing Amelogenin Y. Hum Mol Genet 2007, 16(3):307-316.

37. Saxena R, de Vries JW, Repping S, Alagappan RK, Skaletsky H, Brown LG, Ma P, Chen $E$, Hoovers JM, Page DC: Four DAZ genes in two clusters found in the AZFc region of the human Y chromosome. Genomics 2000, 67(3):256-267.

38. Fernandes S, Huellen K, Goncalves J, Dukal H, Zeisler J, Rajpert De Meyts E, Skakkebaek NE, Habermann B, Krause W, Sousa M, Barros A, Vogt PH: High frequency of $D A Z 1 / D A Z 2$ gene deletion in patients with severe oligozoospermia. Mol Hum Reprod 2002, 8(3):286-298.

39. Nupponen NN, Hyytinen ER, Kallioniemi AH, Visakorpi T: Genetic alterations in prostate cancer cell lines detected by comparative genomic hybridization. Cancer Genet Cytogenet 1998, 101(1):53-57.

40. DeChello LM, Gregorio DI, Samociuk H: Race-specific geography of prostate cancer incidence. Int J Health Geogr 2006, 5(59):2-6.

41. Oishi K, Yoshida O, Schroeder FH: The geography of prostate cancer and its treatment in Japan. Cancer Surv 1995, 23:267-80.

42. Sata F, Umemura T, Kishi R: The epidemiology of PC-recent trends in prostate cancer incidence and mortality. Gan To Kagaku Ryoho 2001 28:184-188.

43. Rahman MM, Bashamboo A, Prasad A, Pathak D, Ali S: Organizational variation of DYZ1 repeat sequences on the human $Y$ chromosome and its diagnostic potential. DNA Cell Biol 2004, 23(9):561-571.

doi:10.1186/1471-2164-14-323

Cite this article as: Yadav et al:: Fate of the human Y chromosome linked genes and loci in prostate cancer cell lines DU145 and LNCaP. BMC Genomics 2013 14:323.

\section{Submit your next manuscript to BioMed Central and take full advantage of:}

- Convenient online submission

- Thorough peer review

- No space constraints or color figure charges

- Immediate publication on acceptance

- Inclusion in PubMed, CAS, Scopus and Google Scholar

- Research which is freely available for redistribution 